Анастасія КОВАЛЕВСЬКА, orcid.org/0000-0002-1031-5546 кандидат філологічних наук, доиент кафедри украӥнської та іноземних мов Одеського регіонального інституту державного управління Начіональної академї державного управління при Президентові України (Oдеса, Україна) ana.kovalevskaya@gmail.com

\title{
НЕЙТРАЛІЗАЦІЯ ПАТОГЕННИХ ДИСКУРСІВ: СТРАТЕГІЯ ТРОЛІНГУ
}

\begin{abstract}
У статті, метою якої є деталізація й ілюстрація стратегій і тактик нейтралізаиії негативного ефекту патогенних текстів політичного дискурсу, досліджено особливості лінгвістичної реалізації впливу на матеріалі промов політичних лідерів європейських країн та текстів новинного характеру, увиразнено специфіку стратегї тролінгу, метою якої с або ескалація емочійності та неправдивості інформації, поданої в оригінальному тексті, або ж доведення поданої в оригінальному тексті інформації до абсурду, щзо уможливить максимальне зниження раціональності сприйняття початкового тексту, а згодом - $і$ довіри як до оригінального тексту почасти, так i до адресанта зазначених текстів. Оптимальним використання стратегї тролінгу є в рамках нейтралізаиї патогенних текстів, створених у парадигмі фейкових, з огляду на скерованість иього типу текстів на подання завідомо неправдивої інформації для ескалації напруженості в інформаційному просторі та дестабілізаиії ситуаиії. Наведено приклади використання всіх тактик зазначеної стратегії (грубий (деструктивний) тролінг, або флеймінг, конструктивний тролінг, перебільшення / зменшення, вікі-тролінг, тактика «великої брехні», тактика сокпаппетінгу), у яких дотримано всіх ознак оригінального патогенного тексту, зокрема й домінантні впливові маркери, а також особливостей стратегії реалізаиї сугестивності оригінального тексту, щцо уможливлює (у разі подання тексту тій самій иільовій аудиторії, яка вже зазнала впливу оригінального тексту) зменшення або нейтралізацію шкідливого впливу оригінального патогенного тексту. Також у роботі окреслено перспективи подальших досліджень у зазначеній галузі з огляду на ї̈ принципову важливість як для виокремлення базових стратегії побудови патогенних текстів та глибинних механізмів їх формулювання, відповідно, впливу на реципієнтів, і способів протидії кожному з типів таких дискурсів, так і для оптимізації інформаційного простору Украӥни в умовах інформаційної війни.
\end{abstract}

Ключові слова: нейролінгвістичне програмування, політичний дискурс, патогенний текст, стратегія нейтралізації, інформаційні війни, фейковий текст, тролінг.

Anastasia KOVALEVSKA, orcid.org/0000-0002-1031-5546

Candidate of Philological Sciences, Associate Professor at the Ukrainian and Foreign Languages Department Odesa Regional Institute for Public Administration of the National Academy for Public Administration under the President of Ukraine (Odesa, Ukraine) ana.kovalevskaya@gmail.com

\section{NEUTRALIZATION OF PATHOGENIC DISCOURSES: REFUTATION STRATEGY}

The article, which aims to detail and illustrate strategies and tactics of neutralizing the negative effects of the political discourse pathogenic texts, explores the suggestion linguistic implementation features o on the material of European political leaders speeches and news text, and emphasizes the specificity of trolling strategy, which is aimed either at escalating the emotionality and falsity of the information presented in the original text, or at bringing the information presented in the original text to the absurd, which would minimize the rationality of the original text perception, and subsequently - trust in the original text partly, and to the addressee of these texts later on. The trolling strategy is optimal in the framework of neutralization of pathogenic texts having been created in the paradigm of fake news, given the orientation of this type of texts to presenting knowingly false information to escalate tensions in the information space and destabilize the situation. The author presents examples of using all the tactics of this strategy (rough (destructive) trolling or flaming, constructive trolling, exaggeration / reduction, wiki-trolling, "big lies" tactics, sockpuppetting tactics), which follow all the features of the original pathogenic text, including the dominant influence markers, as well as the original text's suggestiveness realization peculiaritis, which allows (when presenting the text to the same target audience that has already been affected by the original text) to reduce or neutralize the harmful effects of the original pathogenic text. The paper also outlines the prospects for further research in this area given its fundamental importance not only for identifying 
the basic strategies for constructing pathogenic texts and deep mechanisms of their formulation and, consequently, their impact on recipients, but also ways to counteract each type of such discourses, thus optimizing Ukraine's information space in the conditions of information war.

Key words: neurolinguistic programming, political discourse, pathogenic text, neutralization strategy, information wars, fake text, trolling.

Постановка проблеми й аналіз останніх наукових досліджень і публікацій. Україна, як і всі інші розвинені країни світу, нині перебуває в парадигмі нетократичного соціуму (Бард, Зодерквист, 2004; Ковалевська, 2001), де основним товаром, на відміну від, наприклад, технологій в індустріальній фазі та продуктів в аграрній, є дані, а «той, хто володіє інформацією, володіє світом» (Davis, 1983), а ексклюзивний доступ до неї забезпечує владу над рештою членів соціуму (Бард, Зодерквист, 2004), надає таким чином максимальної ваги нетократичному дискурсу (інформаційна парадигма комунікації), однією з ознак якого (разом із технологічністю, скороченням тривалості життєвого циклу інформації, а отже, підвищенням кількості інформації, яка потрібна для функціонування суспільства тощо) $є$ наскрізна сугестивність і патогенність, які характеризують цей дискурс як «такий, що генерує хворобливі відхилення» (Потятиник, Лозинський, 1996: 35) та «завдає чи, на думку експертів, спроможний завдавати шкоди моральному та психічному здоров'ю окремої особи, нації, держави, людства» (Потятиник, Лозинський, 1996: 209).

3 огляду на те, що саме сугестивність і патогенність $є$ одними 3 визначальних, ключових характеристик цього сучасного суспільства і продукованого ним дискурсу, вони поширюються й на всі його види і типи, зокрема й політичний, який є об'сктом нашого дослідження і який Л. Л. Славова визначає як «сукупність усіх мовленнєвих актів, а також правил публічної політики, які оформилися згідно з існуючими традиціями та отримали перевірку досвідом» (Славова, 2012: 67). Предметом же нашого дослідження, скерованого на деталізацію й ілюстрацію стратегій і тактик нейтралізації негативного ефекту патогенних текстів політичного дискурсу, є специфіка лінгвістичної реалізації патогенності в політичному дискурсі. Для досягнення зазначеної мети необхідно виконати такі завдання: охарактеризувати поняття стратегій і тактик нейтралізації негативного ефекту патогенних текстів політичного дискурсу; виокремити основні стратегії та максимально детально схарактеризувати саме стратегію тролінгу, яка $\epsilon$ фокусом цієї наукової

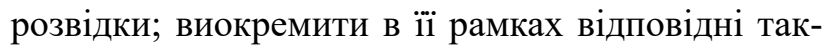
тики, проілюструвати їх прикладами; окреслити перспективи подальших розробок у даній галузі. Фактичним матеріалом дослідження стали зафіксовані протягом 2006-2020 pр. промови, політичні програми, діалоги на пресконференціях тощо європейських політиків (приблизно 200 одиниць кожного типу).

Виклад основного матеріалу. Після визначення базових положень класифікації й ідентифікації патогенності в текстах політичних дискурсів, а також характеристики базовий алгоритм аналізу патогенних дискурсів, скерованих на нейтралізацію негативного ефекту патогенних сугестивних текстів, у попередніх роботах (Ковалевська, 2018; Kovalevska, 2018; Kovalevska, 2017; Kovalevska, Kovalevska, 2020), підкреслимо, що власне нейтралізація негативного ефекту цих текстів спостерігається на третьому етапі за допомогою обрання відповідної стратегії, «визначальної лінії мовленнєвої поведінки у вимірах конкретної комунікативної події, встановлюваної загальною метою спілкування, ситуативно-подійним контекстом, уявою про адресата, сукупністю відповідних пресупозицій» (Загнітко, 2020: 773-774), чи тактики («визначувані комунікативною стратегією мовленнєві кроки, які у своїй цілісності дозволяють досягти основної комунікативної мети» (Загнітко, 2020: 792)) нейтралізації.

Отже, пропонуємо три базові стратегії: спростування, заповнення лакун та тролінгу (Ковалевська, 2018; Kovalevska, 2018), деталізуємо тактики останньої, яка і є фокусом нашого дослідження.

Метою реалізації стратегії тролінгу є або ескалація емоційності та неправдивості інформації, поданої в оригінальному тексті, або ж доведення поданої в оригінальному тексті інформації до абсурду, що уможливить максимальне зниження раціональності сприйняття початкового тексту, а згодом - i довіри як до оригінального тексту почасти, так і до адресанта зазначених текстів. Оптимальним використання стратегії тролінгу $\epsilon$ в рамках нейтралізації патогенних текстів, створених у парадигмі такого типу інформаційних воєн, як «фейк-атака», з огляду на скерованість цього типу IB на подання завідомо неправдивої інформації для ескалації напруженості в інформаційному просторі та дестабілізації ситуації. Саме інформація, сконструйована в рамках цього типу $\mathrm{IB}$, зазвичай завідомо не відповідає дійсності, тож 
доведення іiі до абсурду стає досить простим, 3 огляду на інгерентні внутрішні суперечності, що й уможливлює зниження індексу негативності оригінального тексту.

Під тролінгом зазвичай розуміється «розробка завідомо провокаційних повідомлень 3 метою викликати конфлікти між учасниками мережевого співтовариства, «хвилю правок» (активне цілеспрямоване втручання в текст повідомлень у контексті пропаганди та нав'язування власної позиції), а також увести користувачів у безглузду конфронтацію» (Семенов, Шушарина, 2011: 135) або ж «провокація для досягнення певної мети» (Гуменюк, 2014: 174).

Окремим типом тролінгу дослідники називають політичний тролінг, який відрізняється від усіх інших видів тим, що «має на меті просування власних ідей, у даному випадку - ідей переваги своєї політичної сили і дискредитації конкурентів» (Данько, 2015: 89), найчастіше реалізується в парадигмі так званого «тонкого» тролінгу, коли троль, «зачіпаючи особистісні та професійні якості опонента, впливаючи на нього, виводить 3 рівноваги і викликає відповідні реакції, очікувані тролем» (Акулич, 2012: 51). У контексті же нашої роботи, скерованої на дослідження сугестивних аспектів патогенних текстів та механізмів нейтралізації негативних ефектів зазначених масивів, принциповою ознакою тролінгу вбачаємо потенційну сугестивність породжуваних у процесі цієї діяльності текстів, що вимагає доповнення наявних визначень. Отже, у рамках нашої роботи визначатимемо тролінг як «розробку завідомо провокачійних повідомлень з метою нейтралізаціі негативного ефекту патогенних політичних текстів шляхом або ескалаиії емоційності та неправдивості інформації, поданої в оригінальному тексті, або ж доведення поданої в оригінальному тексті інформаиії до абсурду, щчо уможливить максимальне зниження раціональності сприйняття початкового тексту, а згодом - $і$ довіри як до оригінального тексту почасти, так $і$ до спроможності адресантазазначенихтекстів узагалі».

Отже, у рамках стратегії тролінгу виокремлюємо такі тактики:

1. Тактика грубого (деструктивного) тролінгу, або флеймінгу, що корелює із визначенням «товстого» тролінгу, ініціалізатори якого «ведуть себе досить різко і навіть грубо, їхня думка докорінно відрізняється від думки локальної більшості < ..>, що кращим чином служить досягненню їхньої мети $<\ldots>$ викликати хаос і привернути увагу до своєї особи» (Данько, 2015: 88) (названа за аналогією $з$ таким різновидом тролінгу, як флеймінг, що розуміється як «акт розміщення образ, часто із додаванням нецензурної лайки чи іншого образливого мовлення на сайтах соціальних мереж» (Christensson)). Це тактика, скерована на умисне зниження цінності оригінального тексту шляхом агресивної критики, часто образливої для автора / розповсюджувача тексту, навмисного неправильного написання імен та назв, використаних в оригінальному тексті, і навіть погроз на його адресу, яка, зрештою, має на меті зміщення фокуса із власне наданої в оригінальному тексті інформації на повідомлення флеймера через його максимальну емоційну насиченість 3 огляду на підвищену емоційність і агресивність.

2. Тактики конструктивного тролінгу, що корелює із визначенням «тонкого» тролінгу, прихильник якого «діє на межі правил, прийнятих у місці, де він діє, не порушуючи їх безпосередньо, і часто змушуючи адміністрацію на перевищення повноважень або на порушення власних же правил», володіє водночас «глибокими знаннями в галузі психології, що дозволяє йому впливати на людей 3 використанням більш витончених методів» (Данько, 2015: 88-89). Їхня мета полягає в цілеспрямованому доведенні оригінального тексту до абсурду для зниження як його негативного ефекту, так і довіри до його автора. У рамках тактик конструктивного тролінгу виокремлюємо такі:

a) тактика перебільшення / зменшення, що зворотно пропорційно корелює 3 таким типом неправди, за класифікацією П. Екмана, як перебільшення, коли ми «говоримо правду таким чином, щоб у неї неможливо було повірити», яке є вкрай дієвим, оскільки «грозить виставити опонента посміховиськом у разі подальших дій. Несмішлива інтонація чи вираз обличчя в такому разі також можуть сприяти обману» (Экман: 29). У рамках тролінгу ця тактика буде максимально ефективною в контексті як патогенних текстів, що належать до типу IB «фейк-атака» (оскільки саме для нейтралізації такого типу IB здебільшого і пропонуємо використовувати зазначені типи стратегій), так і для типу IB «слон із мухи» (оскільки в ньому зазвичай наявні певні квантори, які можна відповідно до мети використання тактики зменшити чи збільшити для створення ефекту абсурду);

б) тактика вікі-тролінгу, співвідносна $з$ визначенням Wiki-троля як «людини, яка репостить інформацію з Вікіпедії (чи інших достовірних джерел, як-от блоги істориків тощо), не надаючи жодної емоційної цінності цій інформації. Запощена інформація загалом є правдою, але ії використовують у неправильному контексті для того, 
щоб аудиторія робила неправильні висновки» (Spruds, Rožukalne). У контексті ж нашої розробки визначаємо тактику вікі-тролінгу як таку, у рамках якої не коментується ані власне оригінальний текст, ані його автор, а просто подається максимально достовірна інформація 3 максимально достовірних ресурсів, яка, однак, створює ефект абсурду і зводить нанівець раціональність оригінального тексту;

в) тактика «великої брехні», мета якої - довести повідомлену в оригінальному тексті інформацію до абсолютного абсурду, який О. В. Кравченко визначає як «ненормативну, таку, що не припускає особливої знакової конвенції і не відповідає реальній дискурсивній ситуації, мовну конструкцію, що складається із значущих одиниць і семантично суперечить сформованій мовній картині світу» (Кравченко, 2009: 142). Назва «велика брехня» $\epsilon$ алюзією на пропагандистську техніку "große Lüge”, яку визначають як «брехню настільки «величезну», що ніхто не повірить у те, що хтось мав сміливість спотворити дійсність так безсоромно» (Гитлер, 2003), підкреслюючи, що «люди швидше повірять великій брехні, ніж маленькій; а якщо повторювати іiі досить часто, рано чи пізно люди повірять у неї» (Langer), і увиразнює спрямованість тактики на максимальне спотворення створеної оригінальним текстом дійсності, яке, однак, може виглядати навіть більш вірогідним, ніж оригінальний текст, через підвищення градуса його абсурдності і того, що навіть від максимальної брехні, яку таврують як неправду, усе одно залишається відбиток у масовій свідомості. Зауважимо, що відмінність зазначеної тактики від тактики перебільшення / зменшення полягає в тому, що в рамках останньої гіперболізації зазнає лише дія чи квантор, безпосередньо зазначений в оригінальному тексті, тоді як у рамках «великої брехні» абсурдно гіперболізуються всі глибинні суперечності, наявні в оригінальному тексті. Також підкреслимо, що ми усвідомлюємо ідеологічний фокус цитованих творів і в жодному разі не підтримуємо викладених у них позицій, проте, щоби увиразнити представлену нами техніку нейтралізації негативного ефекту патогенного тексту, уважаємо за потрібне апелювати до деяких їхніх положень, оскільки цей твір $\epsilon$ концентром неприйнятних для українського соціуму норм і мотивацій, які, однак, використовуються у пропаганді країни-агресора, мотивують таким чином необхідність формулювання відповідних механізмів боротьби з ними;

г) тактика сокпаппетінгу (за аналогією з таким різновидом інтернет-тролінгу, як «віртуал», або ж "sock-puppeting" - «актом створення підробної ідентичності в Інтернеті, щоб вихваляти, захищати або створювати ілюзію підтримки себе, союзників чи компанії» (Stone, Ritchel)), механіка якої, на відміну від попередніх тактик, адресантами текстів яких має бути власне нейтралізатор, полягає у створенні фейкового, несправжнього адресанта, який підтримує висловлену в рамках оригінального тексту думку, має робити це настільки незграбно, фанатично і нелогічно, з великою кількістю помилок, за допомогою тез, які легко можна спростувати, щоби цілком дискредитувати іiі та всі раціональні аргументи на ії підтримку, виставити такою, що не варта довіри цільової аудиторії. У рамках реалізації зазначеної тактики нелогічність і неосвідченість прихильника оригінального тексту деяким чином транспонується на власне його ідею, що й уможливлює зниження довіри до нього, отже, і зниження рівня його патогенності.

Проілюструємо тактики стратегії спростування на прикладі патогенного політичного тексту. Зауважимо, що фактичні матеріали залучено не через суб' єктивні політичні вподобання автора, а для здійснення об'єктивного наукового аналізу спектра політичної комунікації, оскільки вони є складниками патогенних політичних дискурсів.

Оригінальний патогенний текст:

«3 приводу розлюднення. Школа, звичайна запорізька школа № 106. Дітям, маленьким діткам, у третьому - четвертому класі вчителі пропонують на уроиі природознавства годувати синичок, тому що вони жовто-сині, українські птиці, i всіляко уникати підтримки, а ще краще полювати на снігурів, тому що снігурі - ие птахи, які символізують кляту Росію. Педагоги украӥнської школи № 106 у Запоріжжі на Украйні перевершили всю наявну на сьогоднішній день украӥнську патріотичну істерику. На уроках у початкових класах вчителі закликали дітей рятувати взимку від голоду синищь і знищувати снігурів <...>. На думку педагогів, синичя, маючи жовто-блакитне розфарбування, символізує собою Украӥну, а червоногрудий снігур уособлює імперське, червоне зло на ім'я СРСР і його правонаступника Росію. Кожен снігур у годівниці, зробленої руками украӥнської дитини, відбирає у синички (Україна) їжу. I із иієї причини снігурів бажано не годувати. I якщо прогнати або наприклад, застрелити снігура із пневматичної зброї, ие буде особливо символічним жестом у боротьбі за перемогу всього Украӥнського. Багато батьків у шочі від ініціативи дітей, яку вони принесли з уроку природознавства» (заява В. Рогова в ефірі передачі «Спеціальний кореспондент», телеканал «Росія-2», 12 грудня 2014 р.). 
3 огляду на тип впливових одиниць, можемо зробити висновок про наявність універсальних квантифікаторів, які надають тексту обмежувальної, екстенсивної модальності; пресупозицій, які надають тексту суб'єктивно-об'єктивної адекватності й істинності, оскільки реципієнт підсвідомо «дешифрує» програмовано вкладений в ці одиниці сенс; 3 розмитою і штучно розширеною неспецифічними словами семантикою. Також реєструємо досить велику кількість повторів, що дозволяють акцентувати увагу на повторюваному елементі тексту.

Отже, на основі аналізу тексту, базуючись на консистентності ознак та перевазі первинних комплексних маркерів впливу, можемо зробити висновок про потенційну впливовість та патогенність аналізованого тексту. Зауважимо, що однією 3 основних ознак, що уможливлює уналежнення його до патогенних, отже, сугестивних, є його фейковість, яку було доведено шляхом аналізу документальних даних, наданих у тексті (місто, номер школи, назва предмета), за допомогою алгоритмів факт-чекінгу (див. Інтернет-представництво проєкту stopfake.org).

Зважаючи на консистентність ознак та чітку перевагу первинних комплексних маркерів впливу, можемо зробити висновок про потенційну впливовість та патогенність аналізованого тексту. За зазначеним набором параметрів можемо визначити формулу стратегії реалізації сугестивності аналізованого тексту і таким чином уналежнити його до типу стратегій негативізації, що і визначає специфіку побудови спростувань (табл. 1).

Зауважимо, що в нейтралізованих текстах дотримано всіх ознак оригінального, зокрема й домінантні впливові маркери, а також особливостей стратегії реалізації сугестивності оригінального тексту, що уможливлює (у разі подання тек-

Можливі варіантів реалізації тактик стратегії тролінгу

Таблиця 1

\begin{tabular}{|c|c|}
\hline № & Приклад вербальної реалізації \\
\hline 1. & 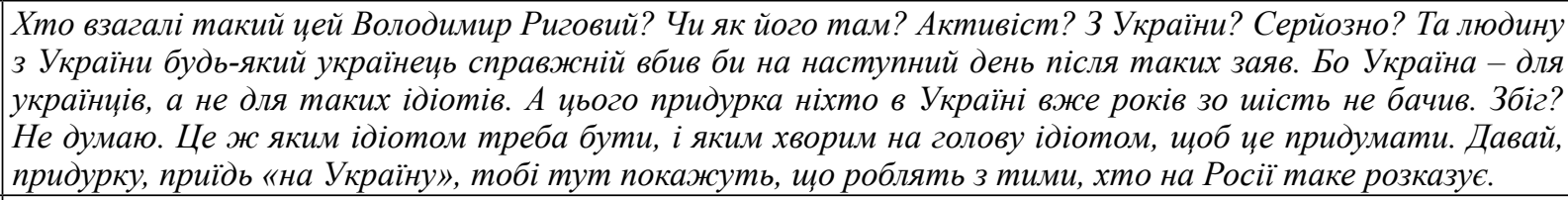 \\
\hline $2 \mathrm{a}$ & $\begin{array}{l}\text { Украйниі снігурів не просто не годують, ми їх ще й труїмо кожного разу, як можемо. У нас навіть спе- } \\
\text { ціяльна отрута для снігурів є, щзоб рідкісна птиця долетіла до середини проспекту Бандери. А синички } \\
\text { настільки розжиріли вже, що навіть літати не можуть, а ходять вуличями і доїдають снігурів, яких ми } \\
\text { недотруїли. Кожного дня це бачу. }\end{array}$ \\
\hline 26 & 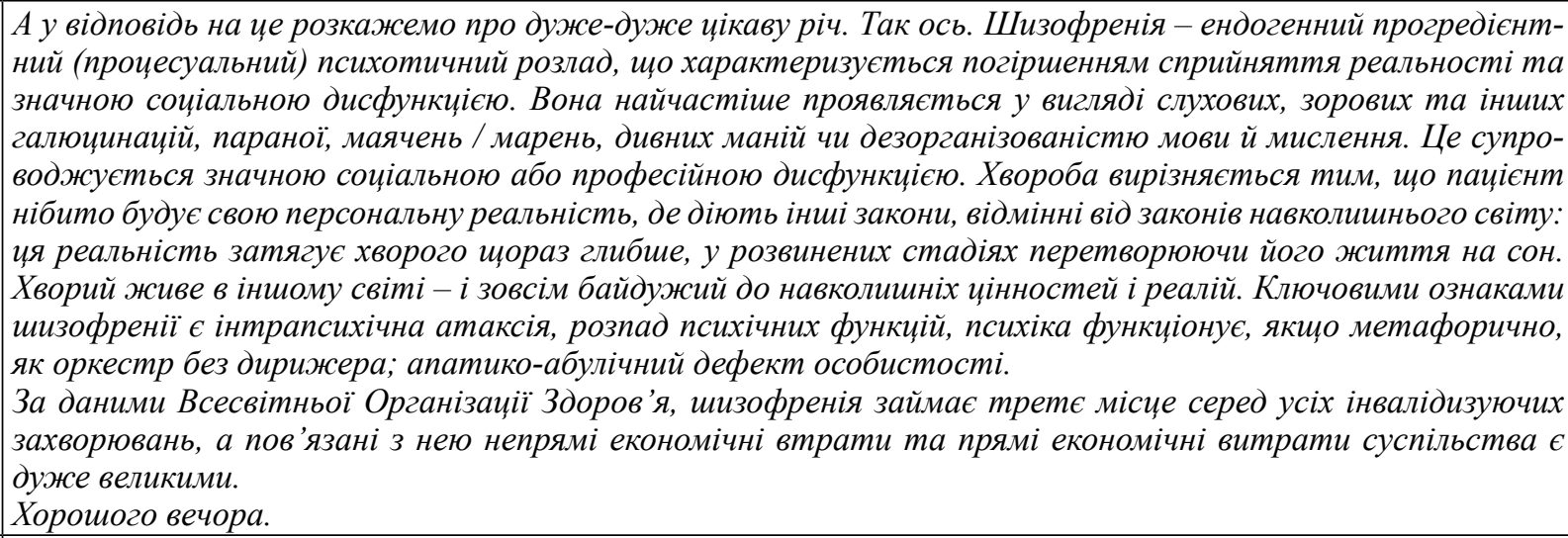 \\
\hline 2B & 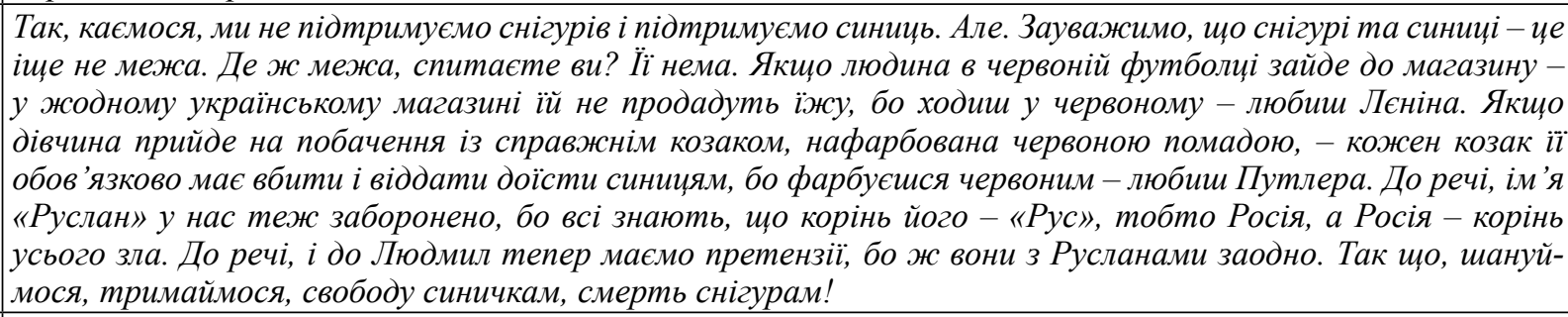 \\
\hline $2 \Gamma$ & 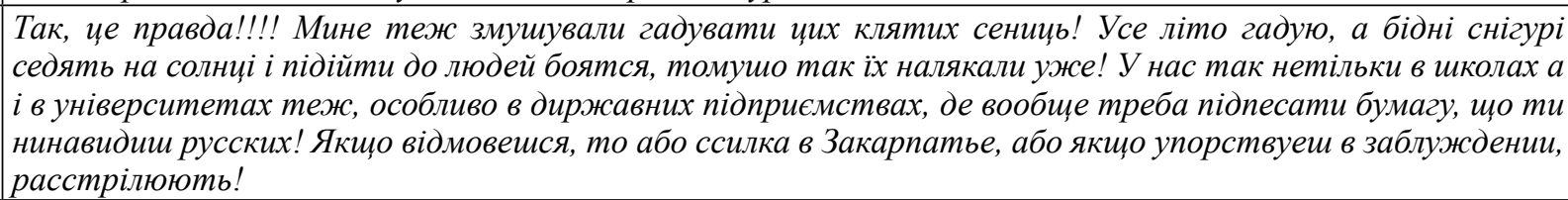 \\
\hline
\end{tabular}


стів тій самій цільовій аудиторії, яка вже зазнала впливу оригінального тексту) зменшення або нейтралізацію шкідливого впливу оригінального патогенного тексту.

Висновки дослідження та перспективи подальших наукових розвідок. Отже, ми представили та проілюстрували на прикладі патогенного політичного тексту кожну тактику стратегії тролінгу і дотримались у нейтралізованих текстах усіх ознак оригінального, зокрема й домінантних впливових маркерів, а також особливостей стратегії реалізації сугестивності оригінального тексту, можемо стверджувати, що впровадження такої технології уможливлює зменшення або нейтралізацію шкідливого впливу оригінального патогенного тексту.

Уважаємо, оскільки запропонована нами стратегія спростування алгоритму нейтралізації шкідливого ефекту патогенних текстів патогенних політичних дискурсів поєднує в собі комплексний науковий підхід у рамках таких новітніх наук, як нейролінгвістичне програмування, сугестивна лінгвістика, спін-докторінг та теорія брехні, то вона дасть змогу не лише виокремити базові стратегії побудови таких текстів та глибинні механізми їх формулювання, отже, впливу на реципієнтів, а й способи протидії кожному з типів таких дискурсів. Це, у свою чергу, прислужиться не лише в деталізації положень зазначених наук, а також іміджелогії, психолінгвістики, PR / GR, стратегічного менеджменту, нейромаркетингу тощо, а й у можливому формуванні релевантних планувальних рішень у галузі державної інформаційної безпеки України, що є важливим аспектом інформаційної політики будь-якої держави, набуває особливого значення в умовах гібридних та інформаційних воєн, у фазі яких нині перебуває Україна, тож підкреслює перспективність подальших розробок зазначеної тематики, що і стане фокусом наших подальших наукових розвідок.

\section{СПИСОК ВИКОРИСТАНИХ ДЖЕРЕЛ}

1. Акулич М. М. Интернет-троллинг: понятие, содержание и формы. Вестник Тюменского государственного университета. 2012. № 8. С. 47-54.

2. Бард А., Зодерквист Я. Nеtократия. Новая правящая элита и жизнь после капитализма. Санкт-Петербург : Стокгольмская школа экономики в Санкт-Петербурге, 2004. 252 с.

3. Гитлер А. Моя борьба. Харьков : ООО «Свитовид», 2003. 704 с.

4. Гуменюк Л. Й. Мережевий тролінг як вид комунікативної поведінки. Науковий вісник Львівського державного університету внутрішніх справ. Серія «Психологічна». 2014. Вип. 1. С. 172-180.

5. Данько Ю. А. Феномен «тролінгу» як форма комунікативної Інтернет-взаємодії: політичний контекст. Вісник Наиіонального університету «Юридична академія України імені Ярослава Мудрого». 2015. № 2 (25). С. 83-94.

6. Загнітко А. П. Сучасний лінгвістичний словник. Вінниця, 2020. 920 с.

7. Ковалевська А. В. Алгоритм нейтралізації патогенних текстів в українському інформаційному просторі. Одеська лінгвістична школа : модерні парадигми : колективна монографія / за заг. ред. Т. Ю. Ковалевської. Одеса, 2018. C. $175-285$.

8. Ковалевська Т. Ю. Комунікативні аспекти нейролінгвістичного програмування : монографія. Одеса : Астропринт, 2001. $344 \mathrm{c}$.

9. Кравченко О. В. Синтаксические механизмы порождения лингвистического абсурда. Известия Российского государственного педагогического университета им. А. И. Гериена. 2009. Вып. 106. С. 141-146.

10. Потятиник Б. В., Лозинський М.В.Патогенний текст. Львів : Місіонер, 1996. 296 с.

11. Семенов Д. И., Шушарина Г. А. Сетевой троллинг как вид коммуникативной деятельности. Международный журнал экспериментального образования. 2011. № 8. С. 135-136.

12. Славова Л. Л. Мовна особистість лідера у дзеркалі політичної лінгвоперсонології : США - Україна : монографія. Житомир : Вид-во ЖДУ ім. І. Франка, 2012. 360 с.

13. Экман П. Психология лжи. Обмани меня, если сможешь. Санкт-Петербург : Питер, 2010. 304 с.

14. Christensson Per. Techterms Computer and Internet Terms Dictionary:Flaming Definition. URL:https://techterms.com/ definition/flaming (дата звернення: 22.11.2020).

15. Davis Richard. The English Rothschilds. London : Collins, 1983. 272 p. URL: https://mawaratytuger.angelstouch16. com/the-english-rothschilds-book-17581yw.php.

16. Kovalevska A. V. Information Wars' Pathogenic Texts Neutralization Algorithm. Записки з украӥнського мовознавства = Opera in linguistica ukrainiana: Fascicullum. 2018. Вип. 25. С. $227-239$.

17. Kovalevska T., Kovalevska A. Utilizing the Neurolinguistic Programming Technologies in Foreign languages Teaching Practice in Ukrainian Universities. Arab World English Journal : Special Issue on English in Ukrainian Context. 2020. P. 184 -193. DOI: $10.24093 /$ awej/elt3.16.

18. Langer Walter C. Office of Strategic Services (OSS) Washington, D.C. With the collaboration of Prof. Henry A. Murr, Harvard Psychological Clinic, Dr. Ernst Kris, New School for Social Research, Dr. Bertram D. Lawin, New York Psychoanalytic Institute. A Psychological Analysis of Adolph Hitler. His Life and Legend. URL: http://web.archive.org/web/20050828111124/ http://www.nizkor.org/hweb/people/h/hitler-adolf/oss-papers/text/profile-index.html (дата звернення: 22.11.2020).

19. Spruds Andris, Rožukalne Anda. Internet Trolling as a hybrid warfare tool: the case of Latvia. Riga, LV : NATO Strategic. URL: https://www.stratcomcoe.org/internet-trolling-hybrid-warfare-tool-case-latvia-0 (дата звернення: 22.11.2020). 
20. Stone B., Ritchel M. The Hand That Controls the Sock Puppet Could Get Slapped. The New York Times. July 16, 2007. URL: https://www.nytimes.com/2007/07/16/technology/16blog.html?ex=1342238400\&en=9a3424961f9d2163\&ei= 5088\&partner $=$ rssnyt\&emc $=$ rss (дата звернення: 22.11.2020).

\section{REFERENCES}

1. Akulich M. M. Internet-trolling: ponyatie, soderzhanie i formy [Internet trolling: concept, content and forms]. Tyumen State University Herald. 2012. Vol. 8. Pp. 47-54. [in Russian].

2. Bard A., Zoderquist Ya. Netokratiya. Novaya pravyashchaya elita i zhizn' posle kapitalizma [Netocracy. The new ruling elite and life after capitalism]. SPb. : Stockholm School of Economics in St. Petersburg, 2004. 252 p. [in Russian].

3. Hitler A. Moya bor'ba [My fight]. Khar'kov: OOO "Svitovid", 2003. 704 p. [in Russian].

4. Humeniuk L. Y. Merezhevyi trolinh yak vyd komunikatyvnoi povedinky [Network trolling as a type of communicative behavior]. Scientific Bulletin of Lviv State University of Internal Affairs. Psychological series. 2014. Vol. 1. pp. $172-180$. [in Ukrainian].

5. Danko Yu. A. Fenomen "trolinhu” yak forma komunikatyvnoi Internet-vzaiemodii: politychnyi kontekst [The phenomenon of "trolling" as a form of communicative Internet interaction: a political context]. Bulletin of the National University "Yaroslav the Wise Law Academy of Ukraine”. 2015. № 2 (25). pp. 83-94. [in Ukrainian].

6. Zahnitko A. Suchasnyi linhvistychnyi slovnyk [Modern linguistic dictionary]. Vinnytsia : TVORY, 2020.920 p. [in Ukrainian].

7. Kovalevska A. V. Alhorytm neitralizatsii patohennykh tekstiv v ukrainskomu informatsiinomu prostori [Algorithm for neutralization of pathogenic texts in the Ukrainian information space]. Odessa Linguistic School: Modern Paradigms: Collect. monograph / ed. by Kovalevska T. Yu. Odesa : PolyPrynt, 2018. Pp. 175-285. [in Ukrainian].

8. Kovalevska T. Yu. Komunikatyvni aspekty neirolinhvistychnoho prohramuvannia : Monohrafiia [Communicative aspects of neurolinguistic programming: Monograph]. Odesa : Astroprynt, 2001. 344 p. [in Ukrainian].

9. Kravchenko O. V. Sintaksicheskie mekhanizmy porozhdeniya lingvisticheskogo absurda [Syntactic mechanisms for generating linguistic absurdity]. Herald of the Russian State Pedagogical University. A. I. Herzen. 2009. Vol. 106. Pp. 141-146. [in Russian].

10. Potiatynyk B., Lozynskyi M. Patohennyi tekst [Pathogenic text]. Lviv: Missionary, 1996. 296 p. [in Ukrainian].

11. Semenov D. I., Shusharina G. A. Setevoy trolling kak vid kommunikativnoy deyatel'nosti [Network trolling as a form of communication]. Int. journ. Of experiment. education. 2011. Vol. 8. Pp. 135-136. [in Russian].

12. Slavova L. L. Movna osobystist lidera u dzerkali politychnoi linhvopersonolohii : SShA - Ukraina : monohrafiia [Linguistic personality of a leader in the mirror of political linguopersonology: USA - Ukraine: monograph]. Zhytomyr: I. Franko ZhSU Publishing House, 2012. 360 p. [in Ukrainian].

13. Ekman P. Psikhologiya lzhi. Obmani menya, esli smozhesh' [The psychology of lies. Fool me if you can]. SPb.: Piter, 2010. 304 p. [in Russian].

14. Christensson Per. Techterms Computer and Internet Terms Dictionary: "Flaming Definition". URL: https://techterms. com/definition/flaming (accessed 22.11.2020). [in English].

15. Davis Richard. The English Rothschilds. London: Collins, 1983. 272 p. URL: https://mawaratytuger.angelstouch16. com/the-english-rothschilds-book-17581yw.php. [in English].

16. Kovalevska A. V. Information Wars' Pathogenic Texts Neutralization Algorithm. Notes on Ukrainian Linguistics = Opera in linguistica ukrainiana. 2018. Vol 25. Pp. 227-239. [in English].

17. Kovalevska T. \& Kovalevska A. Utilizing the Neurolinguistic Programming Technologies in Foreign languages Teaching Practice in Ukrainian Universities. Arab World English Journal: Special Issue on English in Ukrainian Context. 2020. Pp. 184-193. DOI: https://dx.doi.org/10.24093/awej/elt3.16. [in English].

18. Langer Walter C. Office of Strategic Services (OSS) Washington, D.C. With the collaboration of Prof. Henry A. Murr, Harvard Psychological Clinic, Dr. Ernst Kris, New School for Social Research, Dr. Bertram D. Lawin, New York Psychoanalytic Institute. A Psychological Analysis of Adolph Hitler. His Life and Legend. URL: http://web.archive. org/web/20050828111124/http://www.nizkor.org/hweb/people/h/hitler-adolf/oss-papers/text/profile-index.html (accessed 22.11.2020). [in English].

19. Spruds Andris \& Rožukalne Anda. Internet Trolling as a hybrid warfare tool: the case of Latvia. Riga, LV: NATO Strategic. URL: https://www.stratcomcoe.org/internet-trolling-hybrid-warfare-tool-case-latvia-0 (accessed 22.11.2020). [in English].

20. Stone B. \& Ritchel M. The Hand That Controls the Sock Puppet Could Get Slapped. The New York Times. July 16, 2007. URL: https://www.nytimes.com/2007/07/16/technology/16blog.html?ex=1342238400\&en=9a3424961f9d2163\&ei= 5088\&partner $=$ rssnyt\&emc $=$ rss (accessed 22.11.2020). [in English]. 